\title{
Perancangan Media Luar Ruang untuk Kampanye Pencegahan Covid-19 di Komunitas Perdesaan
}

\author{
Muhammad Badri \\ Universitas Islam Negeri Sultan Syarif Kasim Riau \\ E-mail: muhammad.badri@uin-suska.ac.id
}

\begin{abstract}
Abstrak
Pandemi Covid-19 mendorong kewaspadaan berbagai elemen masyarakat untuk melakukan pencegahan, termasuk di perdesaan. Kegiatan pengabdian masyarakat ini bertujuan memberikan pendampingan perancangan media luar ruang untuk kampanye pencegahan Covid19 di Desa Sungaibuluh, Kecamatan Singingi Hilir, Kabupaten Kuantan Singingi. Kegiatan ini melibatkan subjek kegiatan sejak penentuan konsep desain, jenis media, hingga produksi. Proses desain juga memperhatikan prinsip desain yaitu pemilihan bentuk, ilustrasi, warna, tipografi, dan pesan. Kegiatan ini menghasilkan dua jenis media yang dinilai efektif untuk kampanye pencegahan Covid-19 di perdesaan yaitu baliho dan spanduk. Kedua media ini dipasang di tempat umum dan keramaian.
\end{abstract}

Kata Kunci: Covid-19, media luar ruang, pencegahan, perdesaan.

\begin{abstract}
The Covid-19 pandemic encourages the vigilance of various elements of society to take precautions, including in rural areas. This community service activity aims to provide assistance in designing outdoor media for the Covid-19 prevention campaign in Desa Sungaibuluh, Singingi Hilir, Kuantan Singingi. This activity involves the subject of activity from determining the design concept, types of media, to production. The design process also pays attention to design principles, namely the selection of shapes, illustrations, colors, typography, and messages. This activity produced two types of media that were considered effective for the Covid-19 prevention campaign in rural areas, namely billboards and banners. Both of these media are installed in public places and crowds.
\end{abstract}

Keywords: Covid-19, outdoor media, prevention, rural areas.

\section{Pendahuluan}

Pandemi Coronavirus disease (Covid-19) menyebabkan bencana kesehatan di berbagai belahan dunia, termasuk Indonesia. Krisis akibat pandemi Covid-19 telah menggangu tatanan kehidupan masyarakat. Apalagi penyebarannya juga melibatkan banyak transmisi lokal, seperti antar daerah, hingga antar desa. Akibatnya, masyarakat desa menghadapi risiko penularan yang besar seperti halnya masyarakat perkotaan. Menghadapi permasalahan itu, pencegahan penyebaran Covid-19 menjadi sangat penting diterapkan di perdesaan.

Salah satu upaya pencegahan penyebaran Covid-19 di perdesaan yaitu menggunakan media komunikasi yang dapat diakses oleh masyarakat. Komunikasi pencegahan Covid-19 di tingkat desa diperlukan untuk mengatasi kesenjangan informasi dan misinformasi. Sebab di era media sosial, informasi terkait Covid-19 ini 
dapat disebarkan kepada masyarakat luas melalui berbagai media untuk menciptakan ruang informasi pribadi bagi masyarakat (Wang et al., 2020).

Idividu di komunitas perdesaan perlu mendapat perhatian karena terpengaruh pandemi Covid-19. Untuk itu masyarakat perdesaan harus memiliki perlengkapan yang memadai untuk mengatasi penyebaran dan dampak Covid-19. Salah satunya meningkatkan penyebaran pesan kesehatan masyarakat untuk mendapatkan perawatan kesehatan mental dan dukungan krisis di komunitas perdesaan. Meningkatkan penyebaran aplikasi berbasis web gratis juga dapat membantu memfasilitasi penanganan berbagai masalah di perdesaan (Monteith et al., 2020).

Studi pencegahan pencegahan Covid-19 di perdesaan agar berhasil menggunakan semua teknik strategi komunikasi. Desa dapat dinilai sukses melakukan pencegahan penyebaran Covid-19 sampai masa transisi new normal, jika belum ada satupun yang dinyatakan positif Covid-19 ataupun ditetapkan menjadi ODP/ PDP. Untuk itu, pemerintah desa serta para relawan perlu selalu menghimbau masyarakat desa agar tetap menjaga protokol kesehatan dengan selalu memakai masker dan cuci tangan, sehingga diharapkan masyarakat menerapkan PHBS (Nafilah \& Muflihah, 2020).

Untuk kasus di Cina, upaya melawan penyebaran Covid-19 di perdesaan mengoptimalkan peran komunikatif masyarakat. Pengelolaan jejaring dan layanan publisitas pada masyarakat desa dalam pencegahan Covid-19 berdampak besar bagi masyarakat dan berperan langsung dalam mencegah masyarakat agar tidak ke luar rumah. Komunikator pencegahan Covid-19 terdiri atas anggota partai, sukarelawan, dan polisi. Mereka menjadi melakukan komunikasi melalui tatap muka, persuasi, pencegahan, dan paksaan (Wang et al., 2020).

Salah satu kemampuan desa dapat diandalkan dalam rangka penanganan penyebaran covid 19 adalah kemampuan mengarahkan masyarakat desa untuk dapat berpartisipasi dalam program tersebut. Partisipasi masyarakat menjadi kunci utama untuk pencegahan penyebaran pandemi Covid-19. Pemerintah menganjurkan masyarakat untuk menerapkan social distancing (pembatasan sosial) dan physical distancing (pembatasan fisik) guna memotong rantai penyebaran virus tersebut. Dalam penanggulangan Covid-19 di tingkat desa, faktor lingkungan sangat berpengaruh terhadap efektifitas program tersebut. Tanpa adanya dukungan dari lingkungan sekitar, tampaknya mustahil program penanggulangan Covid-19 dapat terselesaikan (Wonok, 2020).

Selain komunitas, sosialisasi juga diperlukan di tingkat keluarga. Beberapa hal yang harus disosialisasikan dan ditaati oleh setiap keluarga untuk mengurangi risiko Covid-19, yaitu: 1) Meminimalisir risiko dengan memerhatikan ventilasi (buka jendela dan pintu) agar udara segar mengalir, hindari dalam ruangan tertutup khususnya pada keluarga yang rentan; 2) Mengatur interaksi dengan menyediakan kamar terpisah jika ada anggota keluarga yang mengalami gejala Covid-19 dan bekerja di luar rumah, serta mengurangi interaksi dengan anggota yang rentan, dan menggunakan masker, khususnya di sekitar lansia dan balita; dan 3) Jaga jarak, jika memungkinkan anggota 
keluarga yang bekerja di luar rumah dan menjaga social distancing (Kaddi et al., 2020).

Untuk keberhasilan kampanye pencegahan Covid-19 di perdesaan diperlukan media komunikasi yang dapat menjangkau semua khalayak. Pemilihan media komunikasi yang dapat diakses semua khalayak penting diperhatikan karena, kesenjangan digital juga terjadi tidak hanya antar pulau, tetapi juga antara pusat kota dan wilayah pinggiran yang mengakibatkan tidak bisa terjadi pemerataan pembangunan di Indonesia. Selain karena kesenjangan digital terjadi di wilayah perdesaan (Nasution, 2016).

Melihat karakteristik masyarakat perdesaan dengan akses internet yang terbatas maka pilihan yang tepat adalah penggunaan media luar ruang. Media luar ruang merupakan sarana penyampai informasi kepada khalayak ramai yang letaknya di ruang terbuka atau ruang publik, seperti di pinggiran jalan, di tengah pusat keramaian, atau di tempat lain yang mudah terlihat oleh banyak orang. Letaknya yang strategis menjadikan media luar ruang sebagai fokus perhatian masyarakat dalam memperoleh informasi yang ada di sekitar mereka (Ekasiswanto \& Wibowo, 2020).

Dalam perencanaan produksi media luar ruang, hal penting yang harus dipertimbangkan adalah penentuan nilai strategis lokasi di mana media luar ruang akan ditempatkan. Beberapa faktor yang menyangkut kondisi lokasi dapat menjadi penentu nilai strategis dan efektivitasnya. Jangkauan atau penempatan media luar ruang sangat penting untuk mendukung efektivitas dari media luar ruang itu sendiri. Kaidah-kaidah yang perlu ditaati dalam penempatan media luar ruang, seperti memperhatikan etika dan estetika lingkungan sekitar serta tidak menutup pandangan rambu, lampu lalu lintas, dan lain-lain (Andra, 2017).

Pada masa pandemi Covid-19 ini, penggunaan bahasa harus diperhatikan pada setiap pembuatan media luar ruang. Oleh karena itu, bahasa yang digunakan harus tepat, eksplisit, dan benar. Agar dapat memperoleh perhatian yang cukup besar pemasangan media luar ruang biasanya dilakukan di lokasi yang strategis. Baliho yang dipasang, misalnya, didesain berukuran besar dan dipasang secara permanen dalam rentang waktu tertentu. Informasi yang dipajang di baliho disusun dengan diksi yang tepat, struktur kalimat khusus, dan berdampak persuasif yang kuat didukung dengan desain yang menarik (Ekasiswanto \& Wibowo, 2020).

Berbagai literatur tentang komunikasi pencegahan Covid-19 di perdesaan dan penggunaan media luar ruang tersebut, memberikan kontribusi dalam pemilihan kegiatan pengabdian masyarakat untuk kampanye pencegahan Covid-19 di komunitas perdesaan. Melihat karakteristik masyarakat di lokasi kegiatan maka media luar ruang dianggap lebih efekif dibanding menggunakan media internet atau media massa lainnya. Pertimbangan pemilihan media luar ruang antara lain: (1) Biaya produksi murah dibanding membuat iklan di media massa; (2) Dapat diakses oleh semua warga desa dari semua kelompok umur dan jenis kelamin; (3) Memiliki daya tarik visual yang lebih baik dibanding media massa dan internet. 


\section{Metode}

Subjek pengabdian ini adalah Pemerintah Desa Sungai Buluh, Kecamatan Singingi Hilir, Kabupaten Kuantan Singingi, Provinsi Riau. Kegiatan dilaksanakan pada MaretApril 2020 di Desa Sungai Buluh dan Kota Pekanbaru. Bentuk kegiatan berupa pendampingan dan konsultasi desain media luar ruang untuk kampanye pencegahan Covid-19. Proses kegiatan diawali dengan identifikasi masalah, ketersediaan sumber daya, dan konsep desain pembuatan media luar ruang. Penulis kemudian melakukan analisis terhadap konsep desain dan mengkaji keselarasannya dengan desain pesan yang tersedia di platform kampanye pencegahan Covid-19 pemerintah yang tersedia di situs https://covid19.go.id/. Proses brainstorming desain media luar ruang dilakukan bersama dengan subjek kegiatan yang diwakili sekretaris desa melalui WhatsApp dan $e$ mail. Berdasarkan diskusi intensif dan analisis psikografis khalayak, maka dibuat konsep desain dengan mempertimbangkan unsur bentuk, ilustrasi, tipografi, warna, dan pesan.

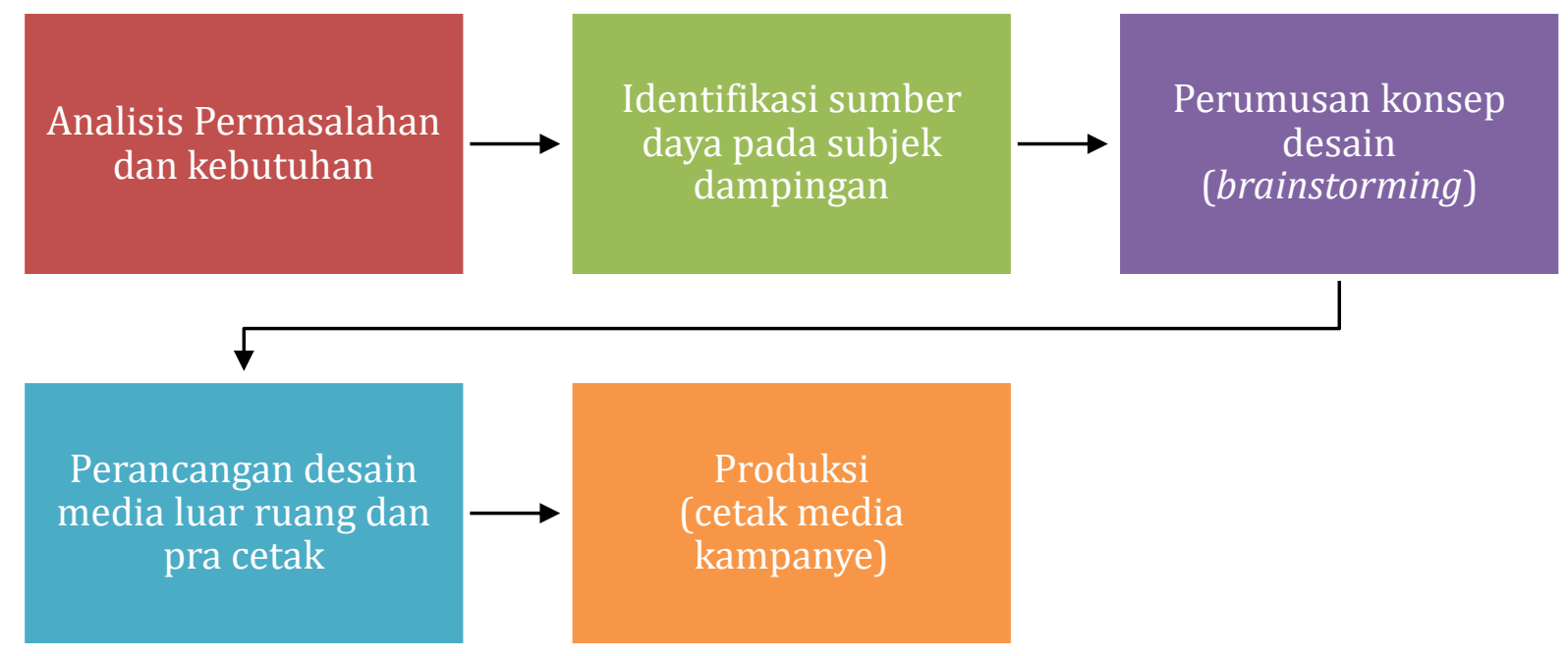

Gambar 1. Proses kegiatan

\section{Hasil dan Pembahasan}

Kegiatan perancangan media luar ruang untuk kampanye pencegahan Covid-19 di Desa Sungai Buluh, Kecamatan Singingi Hilir, Kabupaten Kuantan Singingi, Provinsi Riau telah dilaksanakan. Proses kegiatan tersebut melibatkan dosen pengabdi dan perangkat desa sejak proses perencanaan, perancangan desain, pra produksi, dan produksi. Untuk pemasangan media kampanye dilakukan oleh tim subjek kegiatan.

Secara umum perancangan media luar ruang untuk kampanye pencegahan Covid19 menggunakan prinsip-prinsip desain agar hasilnya efektif sebagai media untuk sosialisasi pencegahan Covid-19 di lokasi kegiatan. Prinsip-prinsip desain yang menjadi pertimbangan dalam perancangan media luar ruang adalah bentuk, ilustrasi (gambar), tipografi, warna, dan pesan. Perangkat lunak yang digunakan yaitu Adobe Photoshop dan Corel Draw. 


\section{Bentuk}

Berdasarkan hasil diskusi dengan subjek kegiatan, bentuk media luar ruang yang dipilih sebagai media kampanye pencegahan dalam pencegahan Covid-19 adalah baliho dan spanduk. Baliho merupakan media promosi luar ruang yang memiliki ukuran cukup besar. Baliho sering digunakan untuk menyampaikan pesan, promosi, iklan, dan berbagai pemberitahuan kepada masyarakat umum. Biasanya baliho dipasang di tempat umum dan strategis (Swastika Advertising, 2019). Spanduk termasuk ke dalam jenis reklame yang memuat informasi baik itu komersial maupun non komersial. Spanduk biasanya berbentuk seperti bendera dengan berukuran panjang yang menampilkan simbol, logo, slogan atau pesan lainnya. Pemasangan spanduk banyak ditemui di jalan raya atau dalam acara tertentu. Selain itu juga harus memiliki isi yang ringkas, padat, dan jelas (Rahman et al., 2018).

\section{Ilustrasi}

Ilustrasi adalah seni gambar yang dimanfaatkan untuk memberi penjelasan atas suatu maksud atau tujuan secara visual (Kusrianto, 2007). Ilustrasi adalah sebuah citra yang dibentuk untuk memperjelas sebuah informasi dengan memberi representasi secara visual. Esensi dari ilustrasi adalah pemikiran; ide dan konsep yang melandasi apa yang ingin dikomunikasikan gambar. Ilustrasi menjadi sumber dari visualisasi pikiran dan ide dan juga menjadi cara untuk mempengaruhi masyarakat dalam hal keyakinan dan tren (Witabora, 2012).

Ilustrasi yang dipilih dalam perancangan media luar ruang untuk kampanye pencegahan Covid-19 adalah ilustrasi virus corona yang dibuat berbasis vektor. Ilustrasi virus corona digunakan untuk latar belakang desain. Ilustrasi utama sesuai permintaan subjek yaitu foto Kepala Desa Sungai Buluh dan logo Kabupaten Kuantan Singingi. Selain itu ada tambahan berupa ilustrasi yang diambil dari situs resmi Satuan Tugas Penanganan COVID-19 (https://covid19.go.id/).

\section{Tipografi}

Di dalam desain grafis, tipografi didefinisikan sebagai suatu proses seni untuk menyusun bahan publikasi menggunakan huruf cetak. Maka "menyusun" meliputi merancang bentuk huruf cetak hingga merangkainya dalam sebuah komposisi yang tepat untuk memperoleh efek tampilan yang dihendaki. Desain komunikasi visual tidak bisa lepas dari tifografi sebagi unsur pendukungnya. Perkembangan tipografi banyak dipengaruhi oleh faktor budaya serta teknik pembuatan. Karakter tipografi yang ditimbulkan dari bentuk hurufnya bisa dipersepsikan berbeda (Kusrianto, 2007).

Desain media luar ruang untuk kampanye pencegahan Covid-19 menggunakan jenis huruf sans serif atau tanpa serif (kait di ujung). Jenis huruf sans serif memiliki karakter modern dan efisien. Jenis huruf ini mudah dibaca dalam jarak relatif jauh, sehingga sesuai jika digunakan untuk media komunikasi luar ruang seperti baliho dan spanduk. 


\section{Warna}

Warna merupakan pelengkap gambar serta mewakili suasana kejiwaan pelukisnya dalam berkomunikasi. Warna juga merupakan unsur yang sangat tajam untuk menyentuh kepekaan penglihatan sehingga mampu merangsang munculnya rasa haru, sedih, gembira, mood atau semangat, dan lain-lain (Kusrianto, 2007).

Desain media luar ruang untuk kampanye pencegahan Covid-19 menggunakan pilihan warna utama merah dan kuning. Salah satu respons psikologis warna merah yaitu kekuatan dan bahaya, sehingga penggunaan warna merah sesuai dengan tujuan komunikasi yaitu memberikan pesan yang kuat tentang bahaya Covid-19. Sedangkian warna kuning menandakan peringatan atau kewaspadaan. Dua jenis warna ini juga lazim digunakan untuk rambu-rambu lalu lintas untuk menyampaikan pesan bahya, hati-hati, dan waspada, sehingga familiar dengan khalayak umum.

\section{Pesan}

Pesan merupakan komponen komunikasi berupa paduan ungkapan pikiran menggunakan lambang, bahasa, atau lambang-lambang lainnya disampaikan suatu pihak kepada kepada pihak lain (Effendy, 2009). Pesan adalah pernyataan tentang pikiran dan perasaan seseorang yang dikirim kepada orang lain agar orang tersebut dapat mengerti dan memahami apa yang diinginkan oleh pengirim pesan (De Vito, 1997). Pesan utama yang disampaikan dalam desain media luar ruang untuk kampanye pencegahan Covid-19 adalah:

1. Waspada corona

2. Kurangi risiko tertular virus corona

3. Gejala klinis terpapar corona

4. Menjaga keluarga dan bangsa

5. Pentingnya melaporkan gejala dan kehadiran pendatang dari luar

6. Jujur memberikan informasi

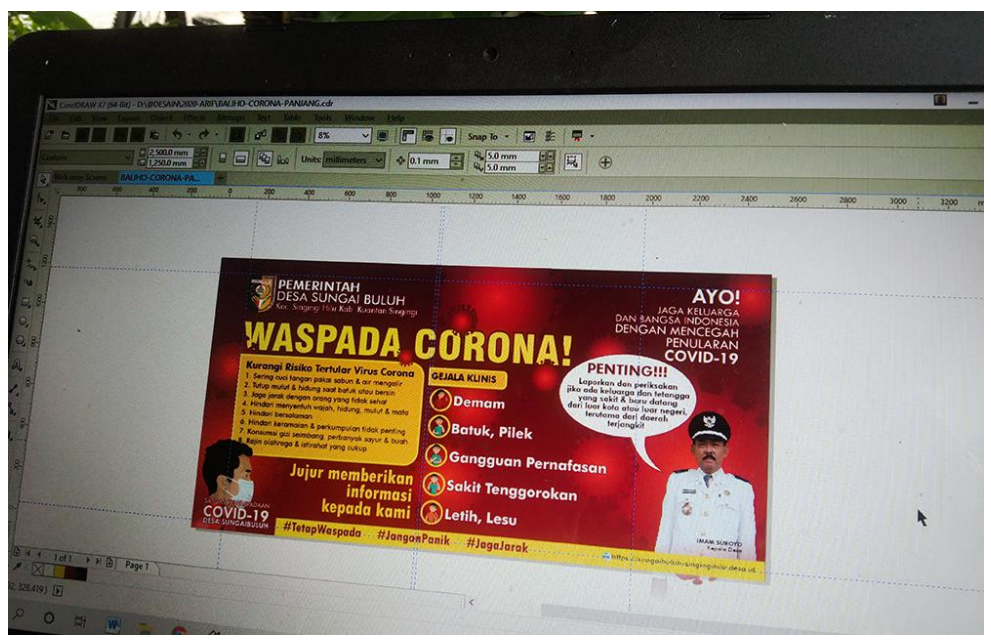

Gambar 2. Proses desain menggunakan Adobe Photoshop dan Corel Draw 


\section{Output}

Output kegiatan berupa hasil karya desain media luar ruang untuk kampanye pencegahan Covid-19 berbentuk baliho dan spanduk. Untuk desain baliho, ukurannya $2 \times 3$ meter dan desain spanduk 1,5x2,5 meter. Desain tersebut dicetak menggunakan teknik digital printing.

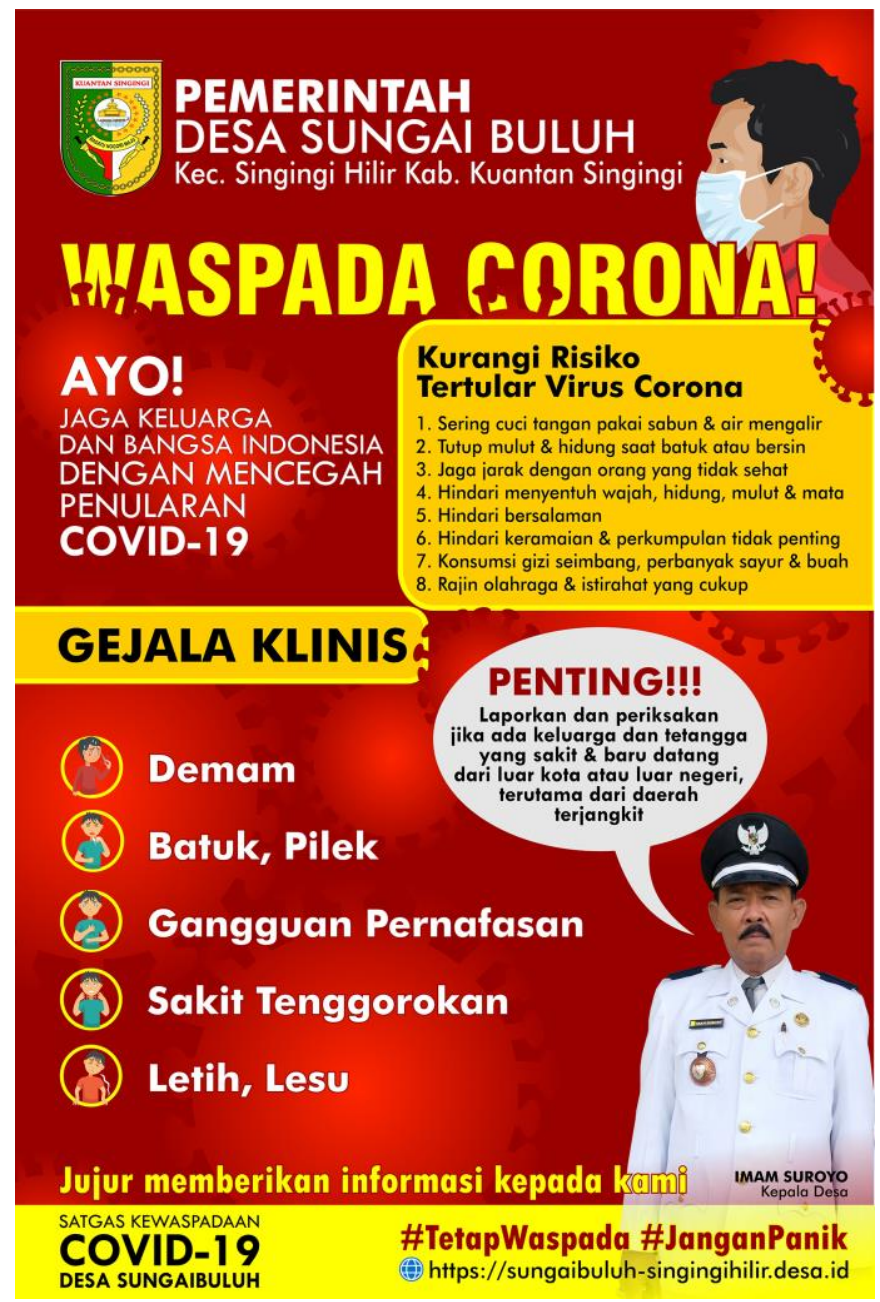

Gambar 3. Desain pracetak baliho untuk kampanye pencegahan Covid-19

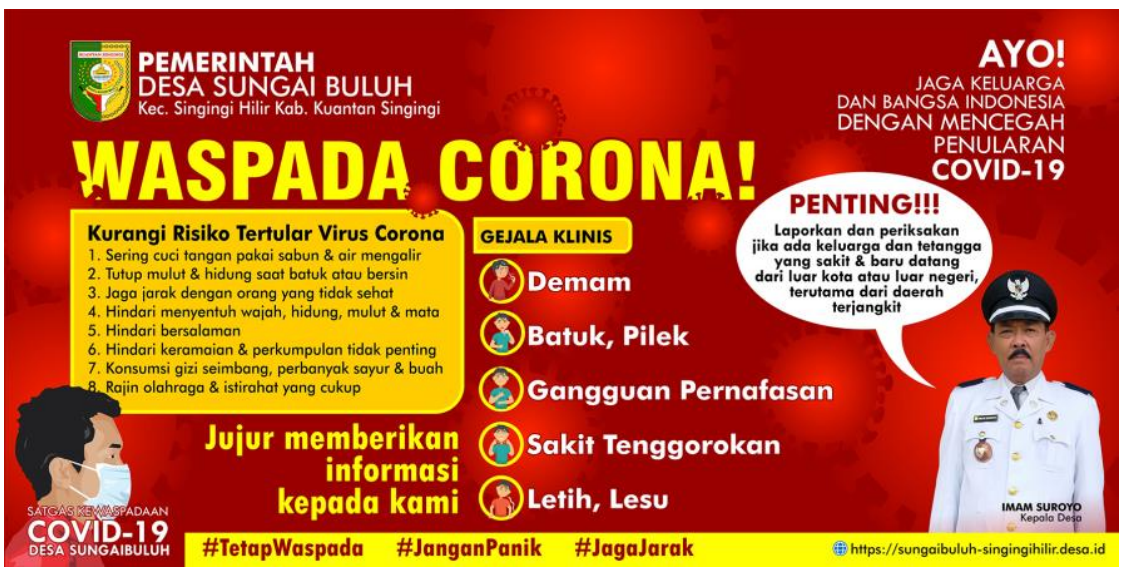

Gambar 4. Desain pracetak spanduk untuk kampanye pencegahan Covid-19 


\section{Pemilihan Lokasi}

Perencanaan penempatan media baliho dan spanduk menggunakan bantuan Google Maps agar hasilnya lebih realistis. Pemilihan lokasi pemasangan baliho yaitu di titik-titik persimpangan jalan, seperti perempatan dan pertigaan dengan tujuan agar media tersebut mudah dilihat oleh pengguna jalan. Hal ini sesuai dengan karakteristik media baliho yang umumnya dipasang di tempat umum terutama yang memiliki arus lalu lintas ramai.

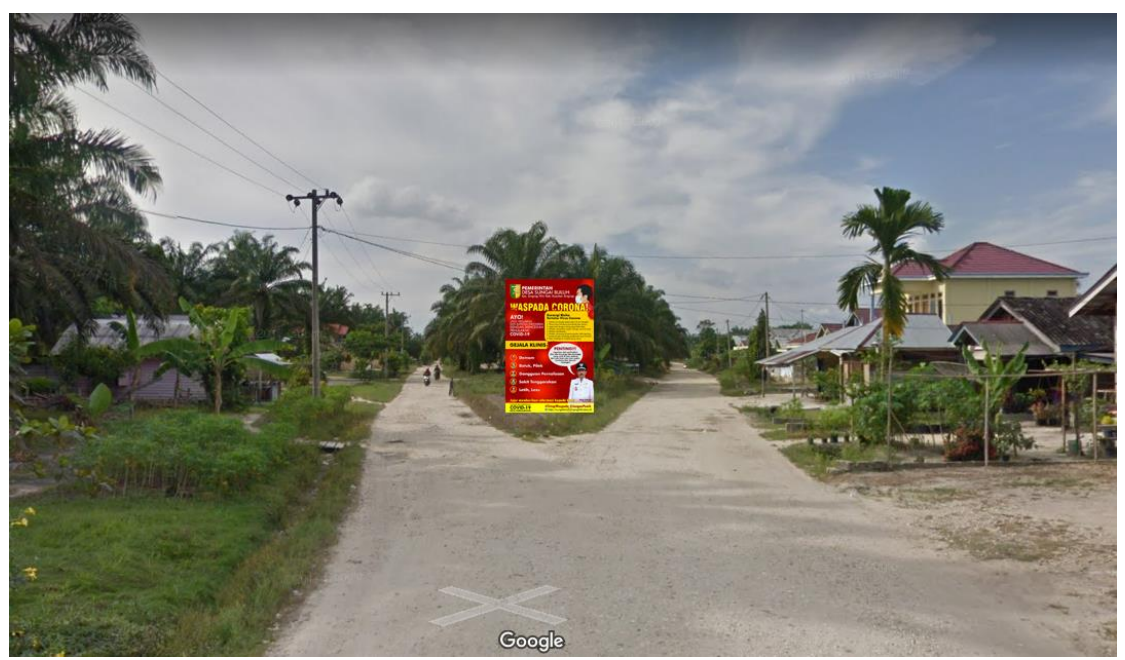

Gambar 5. Ilustrasi pemilihan lokasi pemasangan baliho di persimpangan jalan

Selanjutnya, media spanduk dipasang di lokasi yang berdekatan dengan perkantoran, pasar, atau tempat umum lainnya yang memiliki pagar. Spanduk sesuai untuk dipasang di area yang memiliki pagar agar media tersebut mudah dikaitkan dan tahan terhadap terpaan angin.

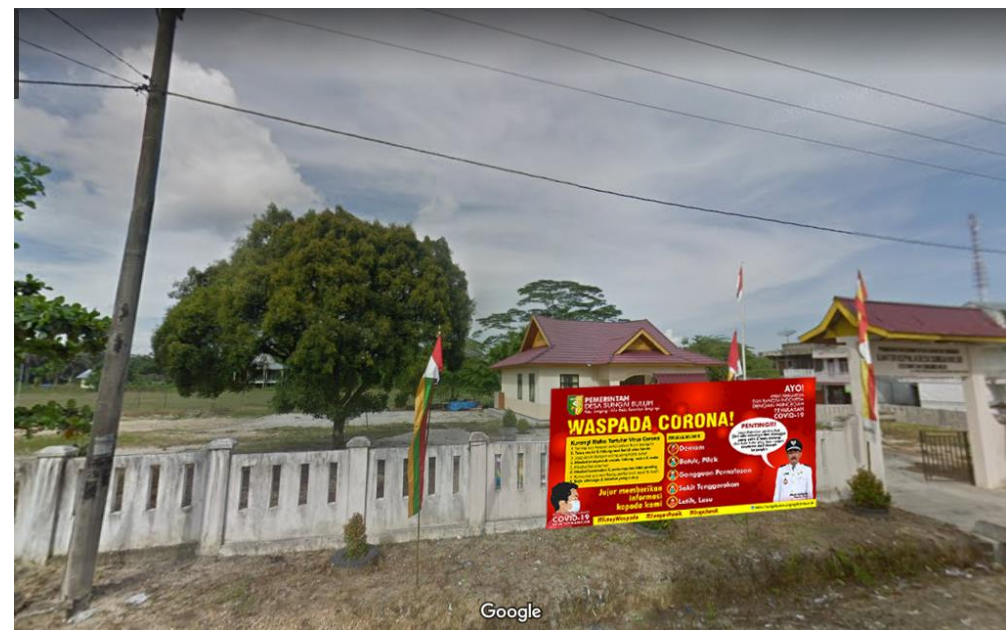

Gambar 6. Ilustrasi pemilihan lokasi pemasangan spanduk di pagar kantor 


\section{Simpulan}

Pandemi Covid-19 menyebabkan krisis yang menggangu tatanan kehidupan masyarakat yang berujung pada peningkatan kewaspadaan untuk mencegah penyebaran Covid-19, termasuk bagi masyarakat yang tinggal di perdesaan. Menghadapi permasalahan itu, pemerintah desa membutuhkan media komunikasi dan sosialisasi pencegahan penyebaran Covid-19 yang mudah diterapkan dan dapat diakses oleh semua masyarakat. Kegiatan pengabdian ini menghasilkan rancangan desain media luar ruang untuk kampanye pencegahan Covid-19 berbentuk baliho dan spaduk. Proses perancangan desain melibatkan subjek kegiatan sejak proses perencanaan, perancangan desain, pra produksi, dan produksi. Hasil desain juga sudah mempertimbangkan prinsip-prinsip desain yaitu bentuk, ilustrasi (gambar), tipografi, warna, dan pesan, agar media komunikasi efektif dan berdampak.

\section{Referensi}

Andra, S. (2017). Efektifitas Penggunaan Media Luar Ruang Dalam Mempromosikan Pariwisata Kota Samarinda. eJournal Ilmu Komunikasi, 2017, 5 (2): 160 - 171

Devito, J. A. (1997). Komunikasi Antar Manusia. Jakarta: Professional Books.

Effendy, O. U. (2009). Komunikasi Teori dan Praktek. Bandung: PT Remaja Rosdakarya.

Ekasiswanto, R., \& Wibowo, R. M. (2020). Pemakaian Bahasa Persuasif Media Luar

Ruang Selama Masa Pandemik Covid-19 di Dusun Nyangkringan, Kelurahan Bantul, Kecamatan Bantul, DIY. Bakti Budaya: Jurnal Pengabdian kepada Masyarakat, 3(2), 183-190.

Kaddi, S. M., Lestari, P., \& Adrian, D. (2020). Komunikasi Keluarga Dalam Pencegahan Coronavirus Disease 2019. Jurnal Ilmu Komunikasi, 18(1), 63-74.

Kusrianto, A. (2007). Pengantar Desain Komunikasi Visual. Yogyakarta: Penerbit Andi.

Monteith, L. L., Holliday, R., Brown, T. L., Brenner, L. A., \& Mohatt, N. V. (2020). Preventing Suicide in Rural Communities During the COVID-19 Pandemic. The Journal of rural health: official journal of the American Rural Health Association and the National Rural Health Care Association, 37(1), 179-184. https://doi.org/10.1111/jrh.12448

Nafilah, Z. A., \& Muflihah. (2020). Langkah Taktis Pencegahan Covid-19 di Desa Lowayu Kecamatan Dukun Kabupaten Gresik. Prosiding Penelitian dan Pengabdian kepada Masyarakat, 7(2), 360-370.

Nasution, R. D. (2016). Pengaruh Kesenjangan Digital Terhadap Pembangunan Perdesaan (Rural Development). Jurnal Penelitian Komunikasi dan Opini Publik, 20(1), 31-44.

Rahman, N. N., Utami, R. S., \& Raden, A. Z. M. (2018). Analisis Tipografi pada Spanduk Pemasaran Perumahan. Jurnal Desain, 5(03), 250-257.

Swastika Advertising. (2019). Macam-macam Media Iklan Outdoor. Retrieved Aug 25, 2020, from https://swastikaadvertising.com/macam-macam-media-iklan- 
outdoor/.

Wang, K., Wang, S., \& Wang, J. (2020, June). Shaping and Publicization of Personal Information Spacec of COVID-19 Information Dissemination. In Journal of Physics: Conference Series (Vol. 1574, No. 1, p. 012169). IOP Publishing.

Witabora, J. (2012). Peran dan perkembangan ilustrasi. Humaniora, 3(2), 659-667.

Wonok, G. R. (2020). Strategi Pemerintah Desa Dalam Pencegahan Penyebaran Virus Corona (Covid-19)(Studi di Desa Mokobang Kecamatan Modoinding Kabupaten Minahasa Selatan). JURNAL POLITICO, 9(1). 